\title{
AGGRESSION AND SIN: AMBIGUITY IN THEOLOGICAL ANTHROPOLOGY
}

\author{
Rick Benjamins \\ Protestant Theological University \\ Leiden
}

\begin{abstract}
Wolfhart Pannenberg developed a theological anthropology which enables us to understand acts of violence and aggression. He rejects the traditional doctrine of man's original state and fall and tries to reformulate the Christian doctrine of sin. According to philosophical anthropology man is an exocentrical being, open to the world, directed outward and constituted by otherness, but at the same time he is selfcentered and concerned with himself. Pannenberg defines sin as the inevitable dominancy of man's self-centeredness over his outward direction. If we take responsibility for ourselves and acknowledge that we have not yet arrived at our destiny, which is given in Christ, we can overcome our self-centeredness by means of an outward directed self-transcendence. Acts of violence and aggression mainly result from the subject's failure to open up to the otherness that is constitutive of its own self, which leads to an offensive self-maintenance.
\end{abstract}

Keywords: Anthropology, Sin, Original Fall, Aggression

Aggression and violence appear in very different forms in our societies. In the South African context violence seems to be present in a brute and physical way, in the Dutch context violence and aggression usually show themselves in the more subtle forms of social discontent, decreasing tolerance and a stiffening urge to fulfill all sorts of needs, which are fed by a growing sense that others should keep to the rules and be more polite to me. It may take historians, sociologists, psychologists and other social scientists to explain the various forms of violence and aggression in different situations, but we also need a theological reflection on aggression and violence, called sin, in order to understand human nature, as it is related to God and neighbour, and offer a hopeful perspective to deal with offences.

Traditionally, the Reformed doctrine of creation and sin made man responsible for the occurrence of inevitable evil, because he is inclined to all wickedness since his fall into sin. This doctrine offered a very fundamental and clear reason for the appearance of violence and aggression, but has come out of favor because of its mythical overtone, its one-sided anthropology and its lack to allow for the ambiguities of evil in biblical narratives. Therefore we need new theological perspectives on human nature and sin that imply a realistic anthropology. This anthropology should avoid cynicism, which takes violence as an inescapable part of human nature, and naïveté, which underestimates the deep roots of violence in man. A theological reflection should be fundamental, abstracted from empirical acts of aggression, offering a theory to understand why people use violence and aggression in order to interpret the various acts of aggression by means of a clarifying conceptual framework.

To my mind Wolfhart Pannenberg elaborated a conceptual framework which may be very useful to discuss violence and aggression from a systematic theological point of view. 
Pannenberg wishes to give a theological account of anthropology, history and the sciences in order to get a fuller understanding of man, his nature and destiny. His thought offers an understanding of violence and aggression based on a theological anthropology which tries to reformulate the Christian doctrine of sin. Pannenberg's theological anthropology was mainly developed in his study Anthropology in Theological Perspective of 1983 and turned out to be very important for his Systematic Theology that was finished roughly two decades later. For a basic understanding of Pannenberg's conceptual framework I will restrain myself to the first chapters of his Anthropology. ${ }^{1}$ These chapters expose an intricate argument, as is often the case with Pannenberg, who generally strikes up conversation with numerous theologians from the past, solves their questions and in the meantime develops an argument of his own. The concepts he develops in Anthropology are fundamental, however, and turn out to be not so complicated after all, but rather encompassing and therefore very rich. In three sections I will discuss Pannenberg's anthropology, his doctrine of sin and his reflections on aggression.

Pannenberg wants to reflect theologically on anthropology and therefore starts with a discussion of the modern philosophical anthropology that was developed by Scheler, Plessner, Gehlen and Eibl-Eibesfeldt. According to these anthropologists man's most fundamental characteristic is his openness to the world. Animals can only react instinctively to appearances. When things turn up in their world, their reactions are predetermined by patterns of behaviour that make them act the way they do. Moreover, animals only react to those appearances or drives that are important for their survival, as Jacob von Uexküll formulated very aptly by saying that in the world of a fly there are only fly-things. ${ }^{2}$ Other things, by nature, are left unnoticed. Human beings, on the other hand, are not limited by a set of drives and instincts. They can be aware of objects in their environment that are useless for their survival and they can attend appearances without reacting, because their perceptions do not automatically release reactions ${ }^{3}$. Therefore, man is open to the world, as Scheler said. ${ }^{4}$ Gehlen thought this openness to the world in fact to be a retardation, a deficiency in the development of human beings because they are born untimely, before their behavioral patterns are finished, because of which man has to compensate his natural shortage by mental skills. ${ }^{5}$

Pannenberg notes that the aforementioned anthropologists show familiarity with the German philosopher Herder in their views of humanity. ${ }^{6}$ Herder thought that man was born imperfect and should develop himself. Man still has to become man by means of selfrealization. He can perform the task of self-improvement because he is endowed with reason and freedom. According to Herder, man's self-realization is guided by the image of God, which is impressed on the human mind and points the way towards religion and humanity, thus giving man a direction in the process of his self-development. Even though the image of God guides human beings, just as instinct guides the behavior of animals, it

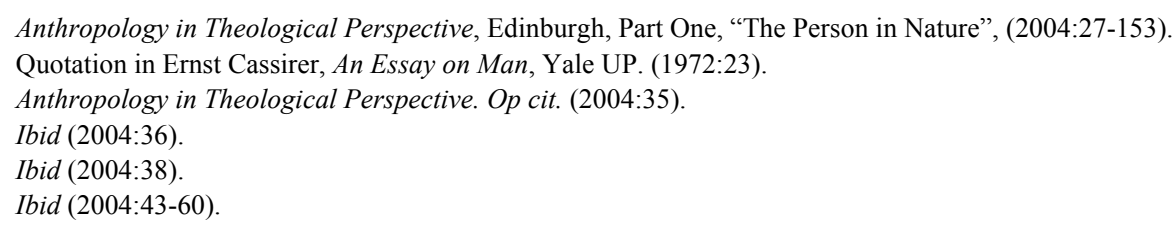


cannot fashion itself. Tradition and learning, reason and experience are still needed to give shape to the image of God in man, who initially possesses only a disposition to reason, humanity and religion. Pannenberg refers to the self-improvement of man as the selftranscendence of man, who is continually overcoming himself in the process of becoming himself. $^{7}$

Openness to the world and self-transcendence are important for the description of humans, but they do not define their being, since they only open up a space for free movement in which man still has to develop himself. The process of self-realization is actually initiated by man's so-called exocentricity as a third characteristic of human beings. 'Exocentricity' simply means that men do not live in a universe of their own, but are directed to the world outside themselves and to what is other than themselves. ${ }^{8}$ Relying heavily on Hegel, discussing several insights from Scheler and Plessner, Pannenberg argues that by exocentricity we have a) the capacity to discern objects objectively, b) the aptitude of self-consciousness in which we are aware of ourselves as objects, and c) an implicit consciousness of God as well, since we can only discern the objects of the world if we transcend them and reach out to what is beyond them, relating ourselves to an Other who embraces the entire world and unifies it beyond all the objects of the world. ${ }^{9}$ We do not need to scrutinize the details of this reasoning and its validity. A lot of speculation and dialectic is involved, but basically, Pannenberg claims that man is only present to himself, when he is present to the world. We are only with ourselves when we are directed towards what is other than ourselves. We live 'ecstatically', which means that we only live when we have our attention, our mind and our being outside ourselves. Our self-knowledge depends on our knowing something else - another person, another object, something outside me for only if I come to know the other as an other, can I look back towards myself and see myself as an other, objectifying both the other and myself. Therefore, "speaking very generally, experience of the world is the way by which human beings reach experience of themselves" and next "the question of human beings about themselves and the question of the divine reality belong together". ${ }^{10}$ Exocentricity then, means to say that we are directed outward first and come to know ourselves next, being implicitly conscious of divine reality at the same time.

By being exocentrically related to what is other than itself, the subject discovers itself or even constitutes itself and from now on, there are two fundamental movements or drives to determine man. On the one hand, man continues to be an exocentrical being, directed outward, open to the world, living ecstatically. But on the other hand the subject's self has originated as a being in becoming and the subject has to take care of itself, is related to itself and concerned with itself. Next to the outward orientation of human life there arises an inward movement that is directed by the need of self-preservation and self-maintenance against the outside world.

The twofold movement of exocentricity and centrality of the subject, which implies a twofold direction of being oriented outwards and inwards, results in a twofold and even opposite interest of human beings. They are open to the world, for it constitutes their being, and they permanently overcome themselves by being present in the world. At the same time, they want to maintain and uphold themselves self-interested against the world. This

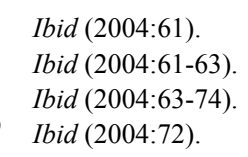


twofold movement of exocentricity and centrality of the subject is fundamental to Pannenberg's anthropology and functions as a key-concept in Systematic Theology. It determines the doctrine of sin, it plays an important role in the Christological chapters of Systematic Theology and it is presupposed in the work of the Spirit that relates man to God.

Anthropological thought is concerned with the exocentricity and centrality of man. Theologically, however, "dogmatic anthropology has had two central themes: the image of God in human beings, and human sin". ${ }^{11}$ These two theological concepts can be seen as the interpretation or implication of the anthropological notions of the exocentricity and centrality of the subject. "To speak of the image of God in human beings is to speak of their closeness to the divine reality, a closeness that also determines their position in the world of nature. To speak of sin, on the other hand, is to speak of the factual separation from God of human beings whose true destiny nonetheless is union with God; sin is therefore to be thematized as a contradiction of human beings with themselves, an interior conflict in the human person". ${ }^{12}$ This means that man can live close to God, in the image of God, if he is exocentrically related to God, but this is prevented by sin, which makes man self-centered. Therefore, human beings contradict themselves, since their self-centeredness and selfpreservation are opposed to their openness to the world and to God beyond the world, which results in an interior conflict in the human being. It may be clear that according to Pannenberg, Christianity does not invent this conflict, but only interprets theologically the conflict that can be found anthropologically.

We will here concentrate on the doctrine of sin, and not on the image of God or man's final destiny, even though we will touch on it in passing, since aggression and sin are our concern. In anthropological terms sin can be defined as the dominance of man's centrality over his exocentricity.

Pannenberg explains how this dominance comes to pass. As we have seen, the peculiarity of human beings consists in their lack of instinct, which makes them open to the world, and this "helps human beings achieve distance from themselves and therefore selfconsciousness or reflection on themselves". ${ }^{13}$ Self-consciousness, however, "manifests a dominance of the centrality aspect of human organization, which reaches its highest point in the central ego, over the exocentricity element in the definition of the human. The central ego turns exocentricity, or the capacity for objectivity that is open to the world, into a means in the service of its own ends". ${ }^{14}$ Thus, because of the dominance of its centrality as a consequence of self-consciousness, the self is no longer directed to the outside world for self-improvement, but rather uses the outside world for its own ends. Sin is precisely this. "The distortion of the relation between the central ego and the exocentric aspect signifies a failure of human beings in relation to themselves, since in their striving to win themselves they neglect their exocentric side". ${ }^{15}$

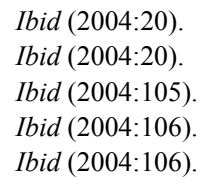


Pannenberg makes clear that there is no escape from sin, for "in their pre-given existential structure all human beings are determined by the centrality of their ego" ${ }^{16}$ Once we have constituted a subjective centre - looking back towards ourselves after being related to some other, reflecting on ourselves and gaining self-consciousness - we experience our selves as the centre of the world. The future is in front of me, the past is behind me, space is left or right from me: me being at the centre of the world. It is inescapable, and it is natural. "If this relatedness of everything to the ego is ... the essential element in sin or the failure of human beings in regard to themselves, then sin is not simply or first of all something moral but is closely connected with the natural conditions of our existence". ${ }^{17}$ The dominance of centrality over exocentricity is the natural outcome of our anthropological structure and this is called sin in theological discourse.

In the course of his argument Pannenberg readily refers to Augustine and Kierkegaard, who developed deep insights and concepts for a better understanding of $\sin .^{18}$ As it turns out, Pannenberg can incorporate their concepts in his own scheme after they have been slightly corrected. In Augustine the amor sui is the root of sin, which is essentially a distortion in the relations of man to the world and to himself. It is not too difficult to recognize some sort of centrality against exocentricity in the notion of amor sui, even at first gaze, and therefore we may allow this topic to rest. For Kierkegaard the concept of anxiety is of great importance to understand sin. Pannenberg discusses it to a considerable extent for his own reasons. Dread or fear in fact is a vague knowledge of the self that knows its own fragility and vulnerability. In the process of becoming, the self knows that its own self is at stake. In anxiety the subject loses its confidence to be founded or constituted by what is other than itself and therefore clings to itself and its own finiteness, trying to found itself, thereby precisely losing itself in despair, as Kierkegaard pointed out in The Sickness Unto Death. Whereas Augustine's amor sui is a manifestation of centrality, it seems to me that Kierkegaard's anxiety rather looks like a failure of exocentricity, since it results from the subject's doubt to found itself exocentrically.

Even though Pannenberg relies on traditional Christian thought to clarify the notion of sin, incorporating notions from Augustine, Kierkegaard and other theologians, he dissociates himself from them by rejecting the doctrine of an original state and an original fall into sin. Already at the start of his study he declares that the dogmatic anthropological themes of the image of God and sin are relevant, if only they are located "outside the framework of the old doctrine of the original state and the fall, a doctrine reflecting a now outdated worldview". ${ }^{19}$ Like Herder, Schleiermacher and others, Pannenberg rejects the doctrine of an original state and fall, but even so he still believes strongly in the idea or thought that is expressed in the notion of original $\sin .{ }^{20} \mathrm{We}$ will have to clarify that.

In the Christian tradition the myth of the original state and fall of man was used to explain how man could come to contradict himself, being opposed to his essential nature. ${ }^{21}$ In man exists both an essential nature and a corruption of it. The myth of the fall can account for this situation. To make man responsible for his own situation, the Fathers of the Church supposed that Adam was created good and turned to the bad by free choice, but Pannenberg argues that this argument cannot be sufficient, since a free choice for evil

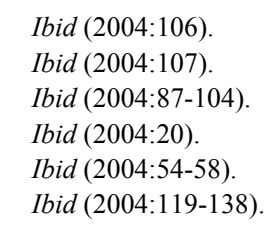


already presupposes a tendency to do evil and thus presumes what it wishes to explain. Augustine developed a doctrine of original or hereditary sin, which clarifies that sin precedes individual man, but does not reduce man's responsibility for evil. Since all men were biologically present in Adam, all sinned in Adam and therefore all are responsible for even that kind of evil that precedes their individual existence. This reasoning of course requires the fall to be a historic fact. Modern theologians like Schleiermacher and Ritschl rejected the doctrine of an original state and fall, but substituted this doctrine by a concept of corporate evil, 'a kingdom of evil' as Ritschl called it, which entangles man as he gets involved in a society full of selfish deeds and reciprocal wrongdoings. In this way, however, actions may be wrong, but not persons, and therefore this is a theory about sins, but not about sin, for which it falls short. In the twentieth century, following Kierkegaard and expressed by Brunner in particular, many theologians took over an existentialist interpretation of the fall, taking the fall as a supra-historical, mythical event that never happened once, but happens all the time. This interpretation was used to account for the fact that man is a sinner from birth, but can still be held responsible for his own sin. Pannenberg argues against it in a complicated discussion that can easily be simplified, to my mind, by the straightforward statement that an original fall never happened, which can therefore still be an adequate expression of evil, but not an explanation for it.

Pannenberg rejects the 'outdated' doctrine of an original state and fall, which captured theologians for centuries, but he clings to the substance of the theological concept of original sin, which "points to a motivational structure that precedes and underlies individual decisions and actions, as being the source of human failure in regard to the self. It is to this structure that Christian theology has given the name 'original sin", 22 The doctrine of original sin, then, expresses that there is something wrong with our nature that underlies our thoughts and deeds, because of which we do wrong. In the previous part we have already seen what is wrong with our nature: it is the dominance of centrality over exocentricity that occurs once a self-conscious subject is established. It is the anthropological structure of man that has grown wrong and makes our decisions and actions wrong, since our selfinterested centrality overrules our openness to the world.

It is not an original fall, but it is our natural anthropological constitution that unsettles us and makes us contradict ourselves. Of course, at this point the crucial question arises, whether we are still responsible for our wrongdoings and shortcomings if they result from our constitution, which is the outcome of a natural process. ${ }^{23}$ Pannenberg argues that we are responsible for our natural constitution, if only we accept responsibility. ${ }^{24}$

Man is not guilty of or responsible for his point of departure, since he cannot help the natural conditions of his existence which precede all his choices. Egoism or narcissism as a consequence of the dominance of centrality over exocentricity is nothing man can be blamed for. But man can transcend his point of departure. Because of our openness to the world, our self-transcendence and our exocentricity, we can overcome the narcissism of our self-centeredness. Human beings have a destination, namely to be 'extra se in Christo'. ${ }^{25}$ It is our destination to have the centre of our existence outside ourselves in God and to become ourselves in Christ, in order to realize our true freedom and to do what is good. In the light of my destination I can accept responsibility for my present existence under

\footnotetext{
Ibid (2004:119).

Ibid (2004:107).

Ibid (2004:134-138).

Ibid (2004:71).
} 
unsettled natural conditions. To accept responsibility means to acknowledge, that in the process of self-becoming I am not yet the person I should be. In Christ our destination is revealed and from that point of view I can take upon myself the responsibility for my actions, my omissions and the entire state I am in. "Only in the light of the revelation of the 'new man' in Jesus Christ as being the fulfillment of the specifically human destiny is it possible to know 'retrospectively' the universality of the sin seen in the figure of Adam as representative of all human beings". ${ }^{26}$ We have to transcend ourselves in a situation of which we are not guilty and for which we are not responsible either. But if we relate ourselves to our selves, we can take responsibility for our selves and acknowledge that we have not yet finished ourselves or arrived at our destiny, which can be reached in Christ.

\section{III}

After he described sin as the dominance of man's centrality over his exocentricity, for which man can take responsibility in the perspective of his destination, Pannenberg deals with the problem of aggression. ${ }^{27}$ Aggression proves to be an ambiguous drive in man and Pannenberg discusses several theories of aggression for a balanced view. His intentions seem somewhat hidden at first sight, but after careful reading his discussions turn out to be very informative about the ambiguity of aggression.

Konrad Lorenz wrote a successful book Das sogenannte Böse in which he showed that aggression is only an evil so called, since it has instinctual roots and is needed for the preservation of the species. This theory causes Pannenberg some problems, because it implies that aggression is inextricably bound up with the centrality of the subject. Lorenz claims that the subject needs some sort of aggression if it wants to maintain itself or its sort. Pannenberg already admitted that there is nothing wrong with the self-preservation of the subject, since self-maintenance is a basic drive of the human being, next to exocentricity. The dominancy of self-preservation over exocentricity is wrong, but if aggression is automatically bound up with the sheer impulse of self-preservation itself, it can hardly be categorically condemned. It seems to me that Pannenberg is willing to recognize this, but he also seems reluctant to accept aggression as something natural to man, since aggression leads to wickedness, and wickedness cannot be accepted as something natural.

Lorenz thinks of aggression as an independent primitive instinct. This theory is derived from Freud's theory of the death instinct. Following Schopenhauer, Freud accepted the existence of pure wickedness, which aims at harming others, not for the benefit and the advantage of oneself, but only for the sheer pleasure of it. Pannenberg argues that this pure wickedness should be rejected, since it is contrary to the Christian doctrine. Such extreme wickedness that aims at harming others without any advantage to itself was always thought to be realized only in the idea of Satan. "Yet even in this instance the destructiveness was regarded not as original but as derivative". ${ }^{28}$ According to Augustine, it was Satan's selflove that made him hate God and all that God had created, so that his wickedness is not an original drive, but the outcome of an extreme self-love, which in turn is the outcome of the

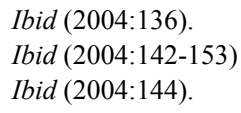


subject's centrality over its exocentricity. Pure wickedness was therefore never considered in Christian doctrine and should be rejected.

I think that Pannenberg's interests are obvious. He does not want to exceed his own conceptual scheme of centrality and exocentricity. If we want to understand aggression within this scheme, it cannot be taken as an original impulse. As an original impulse aggression could imply pure wickedness, which does not conform to Christian doctrine. On the other hand, a relative reason for the occurrence of aggression may be granted, as far as it is related to the self-preservation of the subject, but even so we can never take it as an independent and insurmountable instinct, as Freud and Lorenz suggest. Pannenberg may be right, of course, to refute the independence of an aggressive impulse, but it seems to me that his argument deviates from his aforementioned method in a doubtful way, for in this case theology does not give an interpretation of anthropology, but theology decides about anthropology, since a particular anthropological theory of aggression as an original impulse is discarded on theological grounds.

Because aggression cannot be an independent impulse, Pannenberg turns to a different perspective. "Since 1939, theories of aggression as a drive or instinct have been opposed by the frustration theory" ${ }^{29}$ According to this theory, aggression only appears when the selfassertion and self-expansion of the subject are frustrated. In this way aggression is reduced to a function of self-preservation, which conforms to Pannenberg's scheme of centrality and exocentricity. Aggression only appears when self-maintenance or self-expansion are obstructed. Very often, however, these frustration theories have stimulated aggression, because of their permissive approach, which approves of aggression as an understandable reaction to unacceptable restrictions of natural strivings. Therefore, the frustration theory of aggression can only be accepted on the condition of some corrections. It should not support the aggression used by egocentric persons in favor of their unlimited self-realization, but only admit of the aggression used for self-maintenance, under the restriction that true selfdevelopment will not excuse itself for its own behavior, but will rather conquer itself and overcome its aggressive drives. Implicitly, Pannenberg thereby clarifies that aggression is acceptable only if it is used for the purpose of self-preservation, but cannot be right if it is used for an unrestricted self-expansion. We can transcend our present self-expansion and the aggression related to it, if we overcome our centrality, by being oriented toward Christ exocentrically.

Finally, Pannenberg tries to understand aggression as a manifestation of sin that is deeply related to anxiety. Relying on Kierkegaard, Pannenberg says that anxiety is the way in which the subject is aware of itself and its own fragility and vulnerability in the process of becoming itself. Fear provokes man to cling to himself and to his own finitude, thereby losing himself, since it implies the abandonment of his exocentricity as the only means by which he can become himself. Stuck to himself, man aggressively asserts himself, or gets depressed for having lost himself, or becomes self-aggressive, because he hates himself for the state he is in. Putting it this way, aggression is a mode of the failure of the self and therefore of sin. But sin itself is ambiguous. It is not only a failure of the self, but, as Pannenberg says, it is also "a necessary phase in the process whereby human beings are liberated to become themselves". ${ }^{30}$ The Christian doctrine of sin wishes to make people

Ibid (2004:147)

30 Ibid (2004:152). 
conscious of the responsibility for themselves and of the distance separating them from their divine destiny. Therefore, we should recognize sin in order to overcome it.

In this way Pannenberg offers us a doctrine of sin and aggression which can be summarized as follows: in the course of its development, the exocentric subject becomes self-interested as a necessary outcome of its anthropological structure. The subject can take responsibility for its own situation, recognizing it as sin, when it is aware of its destiny, for which it has to transcend itself. Aggression is bound up with self-preservation and selfexpansion. It should be tolerated to a certain extent, until our present state is overcome, as far as it is related to self-maintenance. It should be overcome, however, as far as it is a manifestation of sin. Aggression is a sin in as far as it is the outcome of the subject's fearful failure to realize itself exocentrically. ${ }^{31}$

To my mind, Pannenberg formulated a very elegant anthropology which is charmingly simple at heart. The conceptual framework of the subject's double drive of exocentricity and centrality can incorporate many classical and modern theories, like the oikeiosis of Stoic philosophy or the origin of the ego in psychological theories. Pannenberg's anthropology can also accept the modern or postmodern notion that the self is not a prefixed substance, but only arises in context. At the same time this theory can integrate the classical notions of sin that Augustine and Kierkegaard developed.

Pannenberg's anthropology shows a plain perspective on acts of aggression. These do not necessarily result from pride or rebellion against God, as the traditional view of an original fall held it, but primarily come forth from fear and the subject's inability to open up to the otherness that is constitutive of its own self. Thus, frustration, fear, vulnerability and impotence seem important motives behind violent acts, since the subject turns to an aggressive self-maintenance because it is unable to preserve or receive itself from the outside. Of course, this is a rather broad view. Its application in a South-African context, where deprivation can make it very difficult to be directed outward with confidence, may be different from its use in a Dutch context, where atomized individuals stick to themselves, but obviously this does not count against a general theory that abstracts from different contexts in order to be universally valid as a global anthropological structure.

I hold this anthropology to be hopeful and realistic. Because of man's self-transcendence, he can overcome himself, his own mistakes and misdoings, if only he understands his own situation and recognizes that he is not destined to live a self-centered life aggressively directed against others. Naturally, man has to recognize this himself. There is no hope outside of man, who can only transcend and transform himself. Precarious as this may seem, it is only realistic to offer no other hope except for the trust in man's selftranscendence. This demands faith in God, who taught man to live exocentrically in Christ and whose image is present in man. Admittedly, it may be very difficult for those engaged in a struggle for survival to think of self-transcendence, but this only intensifies the need for mankind to overcome itself and prevent situations in which sheer survival discards all possibilities of self-transcendence.

31 In The Metaphor of God Incarnate, London 1993:116 John Hick formulated the same view on sin and human nature: "I take it that our endemic individual and corporate self-centredness, from which the many forms of moral evil flow, is an aspect of our nature as animals engaged in the universal struggle for survival; and that this self-centred propensity exists in tension with a distinctively human capacity for ego-transcendence in response to the felt claim upon us of moral values". 
Finally, it follows from Pannenberg's theology that man's destiny is of the utmost importance. The main theme that theology can contribute to any discussion of evil and aggression, which no other science or discipline can deliver, is the subject-matter of man's destination. We can only overcome ourselves, relate to ourselves and accept our present situation realistically, if we know about our destination. We know it, since it is revealed in Christ. Of course, this knowledge is normative and of course we know it in faith only and therefore this knowledge may be denied or refuted. But even so, the knowledge of man's destination is crucial to anthropological thought, and in my opinion it is up to theological thinking to raise this topic in academic or even political debates. It would be a matter of sin to forget about our destination. In fact, sin is precisely this: failure to reach our destiny. 